\title{
Yield and Nutritive Value of LPC \\ Separated From Italian Ryegrass \\ Juice Stored for One or Two Days
}

\author{
Mitsuaki OHShIma* and Hiroshi Ueda \\ Faculty of Agriculture, Kagawa University, Miki-cho, \\ Kagawa-ken 761-07 \\ * Present address: University Farm, Nagoya University, \\ Togo-cho, Aichi-ken 470-01
}

(Received January 14, 1986)

\begin{abstract}
Heat processing of plant juice is the most popular method to coagulate LPC but consumes energy. Alternative to the heat-coagulation method, fermentative coagulation of LPC has been proposed. But we have reported that recovery of protein in LPC was reduced by about $50 \%$ during 7 days anaerobic fermentation of green juice. During the experiment, it was observed that the coagulation of LPC began within 1 day of the storage. So, in the present study, LPC was removed from Italian ryegrass juice stored for 1 and 2 days in sealed bottles. The juice acidified to $\mathrm{pH} 4$ was also prepared and stored as well as the unacidified juice because most of the proteolysis during storage of plant juice can be attributed to the activity of plant enzyme which can be depressed by lowering the $\mathrm{pH}$ of the juice. Even when the juice was anaerobically kept only for 1 day, 20 and $27 \%$ of dry matter and crude protein, respectively, were lost from LPC. But when the juice was treated with $\mathrm{HCl}$ before the storage, the losses were reduced to about a half of those observed in the untreated juice. There was no obvious difference in the yield of LPC between the juices stored for 1 and 2 days. Diets containing $10 \%$ crude protein provided from one of the feeze-dried LPCs and methionine were prepared and restrictedly fed to rats weighing about $50 \mathrm{~g}$ for 10 days. Body weight gain, apparent digestibility of crude protein, nitrogen retention and the ratio of urinary nitrogen to digested nitrogen were determined by the rat trial. All the values were deteriorated by the storage. But the nutritive value of LPC separated from acidified juice stored for 1 day was not so low and significant reduction was only found in the nitrogen retention. While the digestibility of crude protein in LPC separated from the unacidified juice stored for 2 days was quite low compared with others. The lysine content of LPC reflected on the urinary nitrogen excretion of rats. The control LPCs were centrifugally separated from the acidified juice immediately after the acidification or after heating to $70^{\circ} \mathrm{C}$ with a gas burner. The heating process had no effects on both the yield and the nutritive value of LPC.

Jpn. J. Zootech. Sci., 57 (6): 534-539, 1986

Key words: LPC, coagulation method, yield, nutritive value
\end{abstract}

Leaf protein concentrate (LPC) has ordinarily coagulated by thermal processing of plant juice making its cost too high to use as an animal feed. To reduce the cost, fermentative coagulation of LPC has been proposed by some workers ${ }^{1-3}$. But, in our previous studies ${ }^{4,5)}$, it was found that the yield and the crude protein and the available lysine contents of LPC were reduced when green juice was subjected to anaerobic fermentation for 7 days without any other treatments. In the course of the studies, 
it was observed that the coagulation of LPC began within 1 day. And in a preliminary study, adjustment of Italian ryegrass juice to $\mathrm{pH} 4$ with $\mathrm{HCl}$ was found to be useful to coagulate LPC within 1 day without heating. From the facts, it was considered that 1 day's anaerobic preservation of green juice might be available to coagulate LPC, if the yield and the nutritive value of the LPC were comparable to those of thermally coagulated LPC. If some reductions were observed within 1 day, it could be attributed to plant enzyme actions which might be supressed by acidifying the fresh juice to $\mathrm{pH} 4$, because the optimum $\mathrm{pH}$ range for proteolytic plant enzyme is 5.0 6. $0^{6)}$.

The present study has been made to prove the suppositions mentioned above. As the material crop, Italian ryegrass was used, because it ensured higher annual yield of LPC at Kagawa compared with lucerne ${ }^{7)}$ and ryegrass LPC had higher nutritive value than lucerne LPC in chicks ${ }^{8.9)}$. As the controls, LPC separated from the acidified juice immediately after the acidification or after heating to $70^{\circ} \mathrm{C}$ were used. Separation of LPC from acidified juice is possible without heating if such a high speed centrifuge as $15,000 \mathrm{rpm}$ is available. But in plant scale production, the separation of LPC from green juice is made using screw decanters of comparatively low speed and coagulation of LPC before the separation is essential.

\section{Materials and Methods}

Italian ryegrass (Lolium multiflorum) grown in the experimental plots of Kagawa University and harvested on April 9 th and May 8 th, 1985 at the second and the third regrowth, respectively, was used. The stage of maturity, the yield of the crop and the method of green juice extraction are obvious in a previous paper ${ }^{4}$.

Two thirds of green juice was adjusted to $\mathrm{pH} 4$ with $\mathrm{HCl}$ and then subdivided into four equal portions. LPC was centrifugally separated from green juice at 15,000 rpm immediately after the acidification ( $\mathrm{HCl}-0)$, after heating directly with a gas burner to $70^{\circ} \mathrm{C}$ ( $\left.\mathrm{HCl}-\mathrm{Heat}\right)$ and after keeping $1(\mathrm{HCl}-1)$ and 2 days $(\mathrm{HCl}-2)$ in sealed bottles attached with fermentation traps at room temperature $\left(17-27^{\circ} \mathrm{C}\right)$.

Remaining one third of the juice was immediately poured into two bottles, anaerobically fermented for 1 (Fer-1) and 2 days (Fer-2) by sealing the bottles as mentioned above and then subjected to the centrifugal separation of LPC.

Every LPC was freeze-dried, made to fine powder with a ball mill, packed into bottles, sealed with stoppers and stored in a refrigerator of $5^{\circ} \mathrm{C}$.

Rat trials were made as described in an earlier publication ${ }^{10)}$ using diets containing $10 \%$ crude protein provided from one of the LPCs and methionine. Methionine was added $0.4 \%$ of the diets.

Amino acid analysis of LPCs was made on the hydrolysates of intact and performic acid treated samples using Hitachi KLA-5 amino acid analyser ${ }^{11)}$. The nitrogen content of LPCs, diets and excreta was determined by the Kjeldahl method. The significance of the differences of the data was analysed by the Tukey's multiple range test. 


\section{Results and Discussion}

Effect of coagulation methods on the yield of Italian ryegrass LPC is shown in Table 1.

Heating of grass juice abjusted to $\mathrm{pH} 4$ was ineffective in improving the LPC yield suggesting no necessity of the heating if such a high speed decanter as 15,000 rpm is available. But in practical process, it is difficult to use the high speed decanter and some additional treatments are required to coagulate LPC.

Whether the juice was adjusted to $\mathrm{pH} 4$ or not, LPC was coagulated during the 1 day's storage with some reductions of dry matter (DM) and crude protein (CP) recoveries in it. The rate of the reduction was greater in Fer-1-LPC than in $\mathrm{HCl}-$ 1-LPC. DM and CP recovered in $\mathrm{HCl}-1-\mathrm{LPC}$ were 91 and $87 \%$, respectively, of those recovered in LPCs separated from the juice on the day of extraction. They were 80 and $73 \%$ in Fer-1-LPC. These facts suggest that acidification of plant juice is effective in reducing the losses of LPC during the storage by more than $10 \%$, but can not eliminate any losses of LPC. Further 1 day's storage had little effects on both

Table 1. Effect of coagulation methods on the yield of Italian ryegrass LPC1

\begin{tabular}{clccc}
\hline \hline Coagulation method & Abbreviation & $\begin{array}{l}\text { Dry matter } \\
\text { distributed } \\
\text { in LPC }(\%)^{2}\end{array}$ & $\begin{array}{l}\text { Crude protein } \\
\text { content of } \\
\text { LPC }(\%)\end{array}$ & $\begin{array}{l}\text { Crude protein } \\
\text { distributed } \\
\text { in LPC }(\%)^{2}\end{array}$ \\
\hline $\begin{array}{c}\text { Adjusted to pH } 4 \\
\text { and heated to } 70^{\circ} \mathrm{C}\end{array}$ & HCl-0-LPC & 100 & 55.4 & 100 \\
and left for 1 day & HCl-Heat-LPC & 100 & 55.5 & 100 \\
and left for 2 days & HCl-2-LPC & 91 & 52.7 & 87 \\
Fermented for 1 day & Fer-1-LPC & 88 & 52.2 & 83 \\
Fermented for 2 days & Fer-2-LPC & 80 & 50.7 & 73 \\
\hline
\end{tabular}

1. Mean of LPCs prepared from 2 nd and 3 rd regrowth on April 9 th and May 8 th, 1985.

2. Expressed as percent of the highest value.

Table 2. Effect of coagulation methods on the nutritive value of Italian ryegrass LPC in growing rats

\begin{tabular}{lcccc}
\hline Protein source & $\begin{array}{c}\text { Body weight } \\
\text { gain } \\
(\mathrm{g} / 10 \text { days })\end{array}$ & $\begin{array}{c}\text { Apparent } \\
\text { digestibility } \\
\text { of protein } \\
(\%)\end{array}$ & $\begin{array}{c}\text { Nitrogen } \\
\text { retention } \\
(\%)\end{array}$ & $\begin{array}{c}\text { Urinary N/ } \\
\text { Digested N } \\
(\%)\end{array}$ \\
\hline HCl-0-LPC & $31.5^{\mathrm{b} 2}$ & $81.4^{\mathrm{d}}$ & $64.2^{\mathrm{d}}$ & $21.7^{\mathrm{ab}}$ \\
HCl-Heat-LPC & $32.1^{\mathrm{b}}$ & $80.5^{\mathrm{co}}$ & $63.4^{\mathrm{d}}$ & $21.3^{\mathrm{a}}$ \\
HC1-1-LPC & $30.9^{\mathrm{b}}$ & $79.8^{\mathrm{b}}$ & $61.9^{\mathrm{c}}$ & $23.2^{\mathrm{bc}}$ \\
HCl-2-LPC & $29.8^{\mathrm{b}}$ & $78.1^{\mathrm{b}}$ & $58.2^{\mathrm{b}}$ & $25.0^{\mathrm{d}}$ \\
Fer-1-LPC & $28.6^{\mathrm{a}}$ & $78.1^{\mathrm{b}}$ & $58.0^{\mathrm{b}}$ & $25.7^{\mathrm{d}}$ \\
Fer-2-LPC & $28.7^{\mathrm{a}}$ & $74.7^{\mathrm{a}}$ & $56.5^{\mathrm{a}}$ & $24.4^{\mathrm{cd}}$ \\
Pooled standard error & 0.61 & 0.21 & 0.32 & 0.40 \\
\hline
\end{tabular}

1. See Table 1. Each diet was supplemented with $0.4 \%$ of methionine. ${ }^{2}$. Means of 4 rats. Those with different superscript letters are significantly different at $5 \%$ level. 
Table. 3. Effect of coagulation methods on the lysine and sulfur amino acid contents (g/ $16 \mathrm{gN}$ ) of Italian ryegrass $\mathrm{LPC}$

\begin{tabular}{lcccccc}
\hline & & \multicolumn{5}{c}{ Coagulation method } \\
& HCl-0 & HCl-Heat & HCl-1 & HCl-2 & Fer-1 & Fer-2 \\
\hline Lysine & 6.71 & 6.68 & 6.32 & 6.28 & 6.19 & 6.26 \\
Methionine & 2.47 & 2.49 & 2.48 & 2.44 & 2.55 & 2.49 \\
Cystine & 0.90 & 0.89 & 0.94 & 0.96 & 0.94 & 0.96 \\
\hline
\end{tabular}

1. See Table 1.

$\mathrm{DM}$ and CP recoveries in LPC. But it was reported in a previous study ${ }^{4}$ using 5 different cuts of Italian ryegrass that only $62-74$ and $51-59 \%$ of $\mathrm{DM}$ and $\mathrm{CP}$, respectively, of $\mathrm{HCI}-\mathrm{Heat}-\mathrm{LPC}$ were recovered in LPCs separated from the juices fermented for 7 days.

The result of the feeding trial is shown in Table 2. No significant differences were observed between the nutritive values of $\mathrm{HCl}-0$ - and $\mathrm{HCl}-\mathrm{Heat}-\mathrm{LPCs}$ suggesting that the nutritive quality of LPC was not affected by the direct heating of green juice with the gas burner.

During the storage of green juice, some reductions of the nutritive value of LPC have occurred but the rate of the reduction in apparent digestibility of crude protein (AD) and nitrogen retention (NR) was decreased by the acidification. By prolonging the storage period from 1 to 2 days, the nutritive value of LPC was further reduced. That is, NR of rats fed on HCl-2-LPC was similar to that of Fer-1-LPC, significantly higher than that of Fer-2-LPC and significantly lower than that of $\mathrm{HCl}-1-\mathrm{LPC} . \quad \mathrm{AD}$ showed similar tendency to NR and was the lowest in Fer-2-LPC which corresponded to the value obtained in the LPC separated from ryegrass juice fermented for 7 days ${ }^{5}$.

Reflecting these differences, the body weight gain of rats fed on $\mathrm{HCl}-0$ - and HCl-Heat-LPCs was significantly higher than that of rats fed on LPCs coagulated by fermentation. The value of rats fed on LPCs separated from stored acidified juice was between them.

Being able to suppose from the lysine content of LPCs shown in Table 3, the rate of urinary nitrogen excretion to digested nitrogen was greater in rats fed on LPCs prepared from stored juice than in those fed on LPCs prepared on the day of extraction. The reduction of lysine content of LPC during anaerobic fermentation of plant juice was already reported by the authors ${ }^{4)}$ and AmEEnUdDin et al. ${ }^{13)}$. But the rate of the reduction was far less in the present study because of the shorter period of storage. The acidification was not effective in preventing the reduction of the lysine content during the storage. Although there were no significant differences, in spite of being kept for the longer period with fermented juice, Fer-2-LPC contained moro lysine than Fer-1-LPC and consequently the rats fed on the former showed less ratio of urinary nitrogen to digested nitrogen than fed on the latter. There might be some effects of microbial protein. Some workers ${ }^{2,13)}$ reported on the increase of sulfur amino acid contents of LPC during the fermentation of plant juice because of the 


\section{OHshima and Ueda}

contamination of microbial protein, but it was not obvious in the present study.

From the above, it can be concluded that the best method among the procedures used in the present study for coagulating LPC without heating is to acidify the plant juice to $\mathrm{pH} 4$ with $\mathrm{HCl}$ and separate LPC as early as possible when coagulation of it is observed. Even in that case, not only the yield of LPC, but also the nutritive value of it is reduced. Therefore, whether to chose the thermal coagulation or natural coagulation of LPC depends on the difference between the costs expended on heating (A) and loss by the declining yield (B). If (A)-(B) were a possitive value, storage of the acidified juice should be chosen. Acidification of the juice is essential to depress the breakdown of LPC caused by plant enzyme. AJiBora et al. ${ }^{\text {) }}$ recommended the addition of culture of lactic acid bacteria to fasten the $\mathrm{pH}$ reduction and reduce the loss of LPC during the fermentation of plant juice. But it is obvious that the addition of $\mathrm{HCl}$ is more sure method to reduce the $\mathrm{pH}$ value of plant juice than the addition of inoculant. The cost of $\mathrm{HCl}$ is negligible. But the acidification of plant juice is not applicable to some species of lucerne because accumulation of medicagenic acid in LPC occurs by $\mathrm{it}^{14}$.

\section{Acknowledgement}

The authors are grateful to Mr. M. Kamada, Mr. I. Akitomo and Mr. M. Iтo for their help and to the Ministry of Education, Science and Culture for supporting this work by a grant-in-aid No. 59360036 .

\section{References}

1) Stahmann, M. A., Coagulation of Protein from the Juices of Green Plants by Fermentation and the Preservation Thereoff, USA Pat. N 3975546, 1976.

2) Beker, M. J., A. A. Uptis, S. E. Selga, A. A. Klintsare and V. F. Bekere, in A System Analysis Approach to the Assessment of Non-Conventional Protein Product Technologies (Worgan, J. T., ed. ), 57-73, International Institute for Applied Systems Analysis, Laxenburg, 1983.

3) Ajibola, O. O., R. J. Straub, R. G. Koegel and H. D. Bruhn, in Progress in Leaf Protein Research (Singh, N., ed.), 111-127, Today \& Tomorrow's Printers and Publishers, New Delhi, 1984.

4) Onshima, M. and H. UEDA, Jpn. J. Zootech. Sci, 57: 410-415. 1986.

5) Ohshima, M. and H. Ueda, ibid., 57: 416-421. 1986.

6) TRACY, M. V., Biochem. J., 42: 281-287. 1948.

7) Ohshima, M., J. Japan. Grassl. Sci., 32: 72-75. 1986.

8) Ueda, H. and M. Ohshima, Japan. Poultry Sci., 20: 284-293. 1983.

9) Ueda, H., M. Ohshima and M. Kamada, ibid., (in press).

10) Ohshima, M., Jpn. J. Zootech. Sci., 56: 267-273. 1985.

11) Ohshima, M. and H. Ueda, ibid., 53: 622-629. 1982.

12) Ameenuddin, S., H. R. Bird, M. L. Sunde and R. G. Koegel, Poultry Sci., 62: 1021-1024. 1983.

13) Ream, H. W., N. A. Jorgensen, R. G. Koegel and H. D. Bruhn, in Leaf Protein Concentrates (Telek, L. and H. D. Graham, eds), 464-489, AVI Publishing Company Inc., Connecticut, 1983.

14) Ohshima, M. and H. Ueda, Jpn. J. Zootech. Sci., 55: 584-590. 1984. 
1 または 2 日間眝蔵したイタリアンライグラス緑汁液から 分離した LPC の収量上栄養価

\author{
大島光昭* ·上田博史 \\ 香川大学農学部, 香川県三木町 761-07 \\ *名古屋大学農学部附属農場, 愛知県東鄉町 470-01
}

LPC は通常, 加熱凝固法により緑汁液から分灕される が，加熱に多大の然費を要する，緑汁液を嫌兴状態に保 つことによっても LPC は分離するが，1週間の矿蔵中 に約 50\%の蛋白質が LPCから失わ机ることを前報で報 告した. しかしその際, 眝蔵 1 日目で既に LPC の凝固 が観察されたので，今回は，イタリアンライグラス緑汁 液を 1 および 2 日間貯藏したのち LPC を回収した： ま た，詝蔵中の蛋白質分解の多くは植物酵素活性に帰しう るところから，それを抑制する目的で塩酸により $\mathrm{pH} 4$ に調整した緑汁液も同様に眝藏した。

緑汁液を 1 日嫌気条件下に保つ間に，20末よび $27 \%$ の乾物および蛋白質が LPC から失われた．しかし眝蔵 前に塩酸処理することにより，上記の挰失は約 $1 / 2 k と$ どまった。さらに 1 日貯藏しても，LPC 収量に対する大
きな影響はなかった。

凍結乾燥 LPC とメチオニンを単一N源とする粗蛋白 質含量 $10 \%$ の飼料を，体重約 $50 \mathrm{~g}$ のラットに10日間制 限給与した。体重, 蛋白消化率, 尿中N排泄量およびN 保留のいずれの湘定項目も, 緑汁液の詝蔵中に低下した. しかし程酸处理 1 日貯蔵の場合の低下は斿ずかで，N保 留にのみ有意差が認められた，無処理 2 日間貯藏の際の 消化率の低下は，とくに著しかった．尿中N排泄量の増 加と, LPCのリジン合量の低下はよく一致した。

な拉，対照として，緑汁液を $\mathrm{pH} 4$ に調整後ただちに 直火で $70^{\circ} \mathrm{C}$ に加熱あるいは加熱することなく直接高速 遠心により分離した 2 種類の LPC を用いたが，両者の 収量および栄責価に差は認められなかった。

日畜会報，57 (6)：534-539, 1986 